Article

\title{
Adding an Ethical and Spiritual Dimension to Sustainable Business Models
}

\section{Giovanna Bertella}

School of Business and Economics, UiT-The Arctic University of Norway, Tromsø, 9037, Norway; Email: giovanna.bertella@uit.no; Tel.: +47-77646927

\section{ABSTRACT}

This conceptual paper argues for the explicit inclusion of the inherent ethical and spiritual dimensions of sustainability in approaches to business models. The main characteristics of literature on sustainable business models are reviewed. Based on some of the main tenets of ecofeminism and Buddhism, it is observed that some important aspects of sustainability's ethical and spiritual dimensions in the business context are not mentioned or are relegated to a marginal role in the existent literature. To fill this gap, I propose and illustrate a new approach to the creation of sustainable business models, partly inspired by an existent framework that includes some ethics-related elements. This new approach promotes a contextual and relational view of businesses and the cyclical development of the value-related processes underlying business logic. The salient elements of the new model are the multifaceted meanings of value for stakeholders in the specific contexts in which businesses operate, care for and assume responsibility for their various stakeholders. These include the natural environment and the production and consumption mechanisms that aim to satisfy basic needs and promote eudaimonic well-being for consumers and employees.

KEYWORDS: business model; sustainable business model; business ethics; spirituality; ecofeminism; Buddhism

\section{G Open Access}

Received: 06 August 2019

Accepted: 05 September 2019

Published: 06 September 2019

Copyright (C) 2019 by the author(s). Licensee Hapres, London, United Kingdom. This is an open access article distributed under the terms and conditions of Creative Commons Attribution 4.0 International License.

\section{ABBREVIATIONS}

BM, business model; SBM, sustainable business model

\section{INTRODUCTION}

Global challenges, such as climate change, population growth, inequality and loss of biodiversity, require robust scientific solutions. Critics have observed that mainstream approaches have proven limited, and recommend that novel approaches be developed and deployed [1,2]. Recently, some transdisciplinary approaches have emerged in sustainability research. According to Jahn et al. [3], transdisciplinarity can be understood as an approach that integrates various scientific and extra-scientific insights with the aim of contributing to societal and scientific progress. 
The overall purpose of this study is to contribute to the aforementioned stream of research concerning transdisciplinary approaches to sustainability. Specifically, this study adopts as its point of departure scholarly contributions that focus on sustainable business models (SBMs) and reflects on the possible inclusion of relevant ethical and spiritual considerations in such models. In particular, it develops a new approach to sustainability management inspired by some of the main tenets of ecofeminism and Buddhism and by the framework elaborated by Bocken et al. [4] that, when compared with the various SBMs described in management literature, is found to include several relevant ethical reflections [5].

This study's underlying position is that sustainability has an inherent ethical and spiritual dimension. The concept of sustainability emerged during the 1980s and is usually defined with reference to the 1987 UN Brundtland report, which describes sustainable development as a "development that meets the needs of the present without compromising the ability of future generations to meet their own needs" ([6], p. 41). In scholarship on management, sustainability is often linked to the "triple bottom line" framework, which includes economic, environmental and social factors [7]. From these definitions, it is clear that sustainability is a broad concept focused on the relationships that human societies have with the natural environment and with future generations. As suggested by Becker [8], sustainability essentially concerns our responsibilities and obligations towards our contemporaries, nature and future generations. Consequently, it can be argued that the ethical dimension is an integrated part of the sustainability concept.

Several considerations also emerge with regard to the spiritual aspect of sustainability. Spirituality is here understood as the vision of what the human being can achieve if he/she fully develops his/her potentials: spirituality refers to the "deepest values and meanings by which people seek to live” ([9], p. 1-2). According to Zsolnai [10], business ethics and sustainability management require a foundation in spirituality. This is considered essential to overcoming the limitations of superficial sustainable actions, greenwashing and marketing strategies that tend to further stimulate consumerism [11-13]. According to several scholars from various disciplines and backgrounds, spirituality, as a way of life that aligns with ethical values centred on the search for truth and a genuine attempt to serve mankind, is the "missing link" in successful sustainability [14-17].

This study's intention, therefore, is to develop a BM framework that considers the ethical and spiritual aspects of sustainability. This is considered essential in avoiding the so-called unintentional amoral management of businesses (i.e., management that fails to implement ethics due to "the belief that moral considerations have no relevance or applicability in business or other spheres or organizational life” ([18], p. 39). It is believed that a conceptual BM that promotes sustainability 
with the explicit inclusion of ethics and spirituality will discourage this type of management.

This paper is structured in five parts. The first part reflects on some of the challenges and limitations of sustainability. The second part briefly presents the main concepts emerging from the SBM literature, and a description of the framework proposed by Bocken et al. [4]. The third part starts with some reflections on the ethical and spiritual dimensions of businesses, and continues by outlining the main tenets of ecofeminism and Buddhism as concepts that are potentially relevant to sustainability. The fourth part develops and describes the new approach, and, finally, the conclusions highlight the main contributions of this study and comment on some of the challenges associated with the proposed approach.

\section{EXPOSING THE CHALLENGES AND LIMITATIONS OF SUSTAINABILITY}

The conceptual and practical dimensions of sustainability are not immune to challenges and limitations, as was noted by some scholars as early as the 1990s [19]. In 1987, when the UN Brundtland report about sustainable development was published, some scholars noted that the meaning of sustainability is strongly dependent on the context in which it is applied and, therefore, a useful definition must specify explicitly the various characteristics of such a context [20].

The early identification of challenges and weaknesses relative to the concept of sustainability has prompted numerous debates. Among these, several focus on the very foundations of the concept. Some scholars argue that sustainability initiatives are destined to fail if not rooted in the very core of humanity. The particular relevance of the ethical and spiritual values concerning the transcendence of the sense of "I" and the capacity to see the "others", including colleagues at workplaces, business partners, consumers, close and far communities, and nature, is recognised by some scholars [16,18,21].

The latter element, relative to our consideration of nature, has attracted considerable attention in the scholarship. For example, a few years after the publication of the UN Brundtland report, Shearman [22] reflected on the possibility of extending the concept of sustainability to the "biotic community" (i.e., the biosphere, an ecosystem).

Despite such limitations, the UN definition of sustainable development and the related "triple bottom line" framework mentioned in the Introduction represent the almost unanimous interpretation of sustainability in business contexts. 


\section{BUSINESS MODELS FOR SUSTAINABILITY}

The business model (BM) concept is adopted by management scholars as a strategic construct delineating the underlying logic through which value can be created and captured [23,24]. Teece [25] explains what a BM is with reference to "the manner by which the enterprise delivers value to customers, entices customers to pay for value, and converts those payments to profit" (p. 172). It can be noted that the concept of value plays a central role in the conceptualization of BMs. The concept is also used in the analytical description of BMs through the identification of the processes of value proposition, creation and delivery [23,26]. So, what is value?

The meaning of value is broadly discussed in management literature, for example, in terms of monetary benefits, well-being, hedonic appreciation and reduction of sacrifices and negativities [27-29]. This study understands value as an improvement in the condition of an actor, individual or collective: the emergence of value leads to one or more actors becoming "better off" in some respect [28].

Several scholars advocate the integration of sustainability issues in BMs [4,30-37] and it is then important to reflect on the meaning that value acquires in this context [5]. Adopting the analytical description of BMs concerning the processes of value proposition development, value creation and delivery, it can be noted that the identification of the type of value and the beneficiaries of value is of paramount importance. The element of value proposition has traditionally referred to the products and services that the firm offers to its customers. More recently, value propositions have been related to the negotiation of potential benefits for a variety of stakeholders, usually including suppliers, partners, employees and local communities, and value creation and delivery of co-creative practices [38-41]. In SBMs, value propositions are usually concerned with a wide set of stakeholders, including the customers and, for example, partners and local communities. Value creation and delivery are processes concerning the strategic choices related to key activities, resources, channels, partnerships, technology and costs/revenues structures that can contribute to the emergence of economic, social and environmental benefits for the present and future generation of humans [4,37].

Critically reviewing the concept of sustainability, Stubbs and Cocklin [42] consider and discuss the limits of SBMs. Adopting the ecological modernisation perspective on sustainability, the authors propose to include in business logic not only its economic, socio-cultural and environmental characteristics, but also its holistic characteristics, for example, the reduction in consumption and demand-driven production. In this way, they propose a critical consideration of sustainability not only in relation to nature but also in terms of social justice.

As observed by Painter et al. [5], very few scholars have attempted to elaborate SBMs including the ethical aspect inherent to sustainability. 
Among these, Bocken et al. [4] propose a relatively comprehensive framework that includes several ethical aspects of commercial activity, such as the adoption of greener production systems, fair business relations within and across organisations and a shift of production and consumption towards more just and frugal practices.

\section{The SBM Proposed by Bocken et al. (2014)}

Bocken et al. [4] discuss businesses' value-related processes in detail, and identify seven archetypes grouped in three categories: technological, social and organisational. Table 1 shows these categories and the related archetypes. The latter are illustrated by one of the examples used by the authors (italicised in Table 1).

Table 1. The seven SBM archetypes grouped in categories related to the business technological, social and organisational aspects (Adapted with permission from Bocken et al. [4] p. 48).

\begin{tabular}{|c|c|c|c|c|c|c|c|c|}
\hline & \multicolumn{3}{|c|}{ Technological } & \multicolumn{3}{|c|}{ Social } & \multicolumn{2}{|c|}{ Organisational } \\
\hline & $\begin{array}{c}\text { Max. material } \\
\text { and energy } \\
\text { efficiency }\end{array}$ & $\begin{array}{l}\text { Create } \\
\text { value } \\
\text { from } \\
\text { waste }\end{array}$ & $\begin{array}{l}\text { Substitute } \\
\text { with } \\
\text { renewables } \\
\text { and natural } \\
\text { processes }\end{array}$ & $\begin{array}{l}\text { Deliver } \\
\text { functionality } \\
\text { rather than } \\
\text { ownership }\end{array}$ & $\begin{array}{c}\text { Adopt a } \\
\text { stewardship } \\
\text { role }\end{array}$ & $\begin{array}{l}\text { Encourage } \\
\text { sufficiency }\end{array}$ & $\begin{array}{c}\text { Repurpose for } \\
\text { society and } \\
\text { environment }\end{array}$ & $\begin{array}{l}\text { Develop } \\
\text { scale-up } \\
\text { solutions }\end{array}$ \\
\hline Examples & $\begin{array}{c}\text { Increased } \\
\text { functionality }\end{array}$ & $\begin{array}{l}\text { Circular } \\
\text { economy } \\
\text { principles }\end{array}$ & $\begin{array}{c}\text { Renewable } \\
\text { energy } \\
\text { souces }\end{array}$ & $\begin{array}{l}\text { Leasing, } \\
\text { sharing } \\
\text { solutions }\end{array}$ & $\begin{array}{c}\text { Fair trade, } \\
\text { biodiversity } \\
\text { protection }\end{array}$ & $\begin{array}{c}\text { Consumer } \\
\text { education, } \\
\text { frugal } \\
\text { business }\end{array}$ & $\begin{array}{c}\text { Hybrid } \\
\text { business: social } \\
\text { enterprise, } \\
\text { cooperatives }\end{array}$ & $\begin{array}{c}\text { Collaboration, } \\
\text { incubators }\end{array}$ \\
\hline
\end{tabular}

Each archetype represents underlying mechanisms of innovation in business logic that can lead to sustainable value. The idea is that innovation towards sustainability can be realised through technological, social and organisational changes. The archetypes based on technology-oriented innovations are maximisation of material and energy efficiency, creation of value from waste, and substitution with renewables and natural processes. The archetypes based on social innovations are delivery of functionality over ownership, adoption of stewardship roles, and encouragement of sufficiency. The archetype concerning the business stewardship role is also related by Bocken et al. [4] to the environment. As explained by the authors, this archetype seeks to maximise in the long-term the well-being of all stakeholders, including the natural environment. Also included in this group of archetypes are fair trade practices, solutions that seek to reduce the production and consumption of goods (responsible promotion) and provision of products and services to low-income markets (frugal business).

Finally, repurposing for society/environment and development of scale-up solutions are archetypes based on organisational innovations. These archetypes prioritise the delivery of social and environmental 
benefits rather than economic profit maximisation. As suggested by the examples provided by the authors, this can be achieved through close integration between the firm and all the stakeholder groups and the large-scale promotion of sustainable practices.

\section{ETHICAL AND SPIRITUAL DIMENSIONS OF BUSINESSES}

During the 1980s, the theory of business ethics was perceived as a promising and even revolutionary paradigm that could enable business to go beyond the narrowly focused goal of maximising profits. Zsolnai [10] argues that such promises have not been kept: the reality of the financial crisis and, even more, the persistence of global inequalities have neither been stopped nor considerably mitigated by business ethics-related tools such as corporate social responsibility, stakeholder management and collaboration and green technology. Zsolnai then asks what more business ethics can offer in today's economic climate of uncertainty and distrust.

To reflect on and answer this question, several scholars propose the more explicit inclusion of ethical and spiritual perspectives in business practice and theory. For example, Thaker [43] argues that business challenges cannot be met only through knowledge-based tools, and organizations that aim for long-term competitiveness and sustainability would benefit from the development and implementation of "pathways" towards spirituality. Banyhamdan et al. [44] discuss potentially relevant "pathways", identifying some main cultural and structural components that might contribute to move an organization towards a more spiritual approach to business. The inclusion of ethics and spirituality is also highlighted by Balog et al. [45] in relation to a more complete and even realistic way to study entrepreneurial practices.

Moreover, some scholars argue that ethics and spirituality can improve human well-being and contribute to the emergence of a sense of community within and beyond the organisational and economic context [10,21,46-49]. For example, Karakas [48] observes that an ethical and spiritual approach to business can improve the employees' performances and, consequently, the effectiveness of organizations. Adopting a broader view, Corner [50] and Pavlovich [51] note that the ethical and spiritual notions of connectedness and self-awareness are keys to responsibility and sustainability in business.

This study focuses on ecofeminism and Buddhism as relevant perspectives from which to consider an alternative approach to business and sustainability and, more specifically, to revisit the SBM approach.

\section{Ecofeminism}

Ecofeminism is a value system that is concerned with our position as humans in the world, in relation to other humans, as well as to animals and nature [52,53]. Ecofeminism adopts a critical stance towards today's dominant economic and political systems [54]. Ecofeminists argue that, at 
the present time, characterized as the Anthropocene age-the age in which human influence is changing the planet in ways that are irreversible and destructive-a paradigm shift is necessary. This implies rethinking businesses and moving beyond the "artificial and even false categories of perpetual economic growth, so-called free-trade, consumerism and competitiveness" ([54], p. 10).

According to ecofeminism, relationships among humans, at both the individual and collective levels, and between humans and nature should be characterised by care and responsibility. Regarding the latter, ecofeminists argue that there is an implicit and rarely debated utilitarian view of nature, both in Western societies in general and at the basis of traditional environmental theories [53-55]. On the contrary, ecofeminists, especially those who promote the so-called care tradition, emphasise the moral responsibility that we humans have towards nature, recognised as an entity that has an inherent value, and towards animals as individuals [56]. Regarding animals, entangled empathy (i.e., an attitude of connectedness not limited to concerns for the suffering of others and including perspective-taking and emotional sharing) is advocated [57].

Another characteristic of ecofeminism is its contextual approach to ethical reasoning. Ecofeminism recognises the existence of a plurality of interests and the absence of an absolute principle that is valid in all contexts [58,59]. An important consequence is contextual decision making: any moral decision is embedded in a specific situation, and moral challenges can hardly be resolved through the application of a one-size-fits-all solution.

Ecofeminists recommend the development of such values of care, responsibility and plurality not only in the private sphere of our lives but also as part of a political agenda [59]. They argue that debates about economic systems relevant to the sustainability of the earth's ecosystems cannot be regarded as the exclusive domain of economists [60]. Rather, ecofeminism advocates a critical evaluation and a revitalisation of businesses towards a "healthier" direction, inclusive of the interests of all humanity and all of life.

Several scholars have discussed the adoption of ecofeminism in business contexts [60-63]. Ecofeminism is regarded as a critical voice in organisational theory and practice, particularly in relation to the following dominant business mindsets:

- domination (viewing oneself as superior to others and morally permitted to dominate the latter),

- objectification (insensitivity and lack of empathy towards others and possible exploitation),

- dissociation (the limited ability to be aware of and reflect on one's own feelings and beliefs; adoption of hierarchical dualisms and stereotypes). 
Some scholars argue that ecofeminism, due to its emphasis on empathy, relations and flexibility, can provide a useful platform for organisational changes relevant to various business practices, for example, workplace conditions, business networking and environmental responsibility.

Crittenden [62] notes that ecofeminism is not necessarily in conflict with concepts such as profit and consumerism. While this may sound provocative, what Crittenden characterized as "ecofeminist capitalism" differs from the capitalist paradigm considered "patriarchal" by ecofeminists. Profit can derive from fair processes of exchange and responsible actions, and consumerism can have an ethical relevance, for example, when directed towards products and services deriving from fair trade. Moreover, the set of relations implied in business and occurring between individuals, organisations, communities and ecosystems can be caring and meaningful and, consequently, may lead to the emergence of reciprocal value.

\section{Buddhism}

Buddhism, one of the most widely diffused religions worldwide, has as its basis the teachings attributed to the Buddha, Prince Siddhārtha Gautama, who was born in 623 BC in Nepal. In the nineteenth century, Buddhism began to be studied and practised in the Western world. It gained considerable popularity following the success of Herman Hesse's 1975 book Siddhartha. In the Western world, Buddhism is often regarded as a philosophy and a lifestyle, and can be described as a virtue-oriented, character-based and community-focused ethical code [64].

Several scholars have identified Buddhism as a valuable source of inspiration for rethinking the dominant Western political and economic system in favour of a more just and ecologically sound system [65-68]. As observed by Zsolnai [69], Buddhism challenges some "basic principles of modern Western economics, namely profit maximisation, cultivating desire, introducing markets, instrumental use of the world, and self-interest-based ethics” (p. 88). As an alternative to these principles, Buddhism embraces a frugal lifestyle, the simplification of desire, the practice of contentment, moderation, genuine care for others and generosity [69-71]. These practices form the basis of what is termed the "Right Livelihood". Buddhism can "tame" materialism through its ethical doctrines of compassion, loving kindness, empathetic joy and equanimity [70]. For consumers, this implies the engagement in deep reflections on the effects of "tanha" (craving, desire for pleasure objects and greed) and, eventually, the choice of acting out of "chanda" (sincere desire for well-being)[71-73]. Similarly, following the principle of the "Right Livelihood", businesses founded in Buddhism are guided by a "no-poverty and no-affluence" ethic, whereby priority is given to the satisfaction of basic needs for all, without greed or materialistic craving $[69,74]$. Consumers and businesses that choose the "middle way" between 
the extremes of poverty and the materialistic search of wealth for its own sake can do a little good, inspire others and make more visible the existence of a worldwide community of caring people [67,73].

The Buddhist approach to business has specifically implemented certain techniques, such as visualisation and meditation [75]. These practices can lead to healthier work conditions in line with the achievement of eudaimonia - a sense of meaningful happiness based on the perception that one is doing something that is good for oneself and for others. The act of transcending "ego-centredness" can lead to the development of empathy, a compassionate attitude toward all sentient beings, and can facilitate the emergence of virtuous caring relations between persons, communities and ecosystems.

Focusing on sustainability, Kovacs [70] comments on the Buddhist teaching of impermanence and the principles of growth. Sustainability can then be conceptualised as a journey along which we, as individuals and communities, direct our lives toward the achievement of wisdom and social stability. Suh [74] describes the Buddhist perspective on sustainability as centred on social cohesion and environmental quality. Moreover, due to the human nature of some of the most impellent global challenges (for example, climate change), sustainability and the related necessary actions are also considered in relation to the concept of karma, the chain of intentional actions and consequences [76].

Regarding the natural environment, Buddhism does not include any particularly developed thought [77]. Buddha did not experience any environmental crises comparable to those that the planet faces now. His focus was on human suffering, and nature and its value had a secondary role in his reflections. Nonetheless, Buddha encouraged his followers to extend the spirit of non-harming toward all living beings and also toward nonsentient nature. Moreover, several Buddhist scriptures reflect on the interconnectedness of humans and nature. Consequently, Buddhism can be viewed as a source of valuable insights concerning environmental virtue ethics [70,78-80]. Although there is no direct reference to environmental thinking in early Buddhism, several Buddhist principles and practices can be viewed as a solid basis for an eco-friendly and animal cruelty/exploitation-free human lifestyle.

\section{THE PROPOSED SBM}

The proposed model is meant to overcome some of the limitations of the traditional way to understand sustainability, such as the marked anthropocentrism and even egoism [16,18,21,22], and to contribute to the SBMs literature in the direction indicated by Stubbs and Cocklin [42], i.e., a more holistic and just approach to business. The framework developed by Bocken et al. [4] and the aforementioned aspects of ecofeminism and Buddhism form the basis for the development of a new SBM model. In particular, the new model is based on the following: 
- The relevance of moral responsibility in business contexts;

- A contextual and interconnected view of businesses;

- A multifaceted understanding of value according to the plurality of stakeholders;

- Interconnectedness understood also as a karma-like principle;

- A fundamental caring attitude and consequent actions by businesses towards others, including humans and nature;

- The view of work as a means to a life wherein one's basic needs are satisfied and eudaimonic well-being is achieved.

Figure 1 illustrates the proposed model, which is then described in the text that follows.

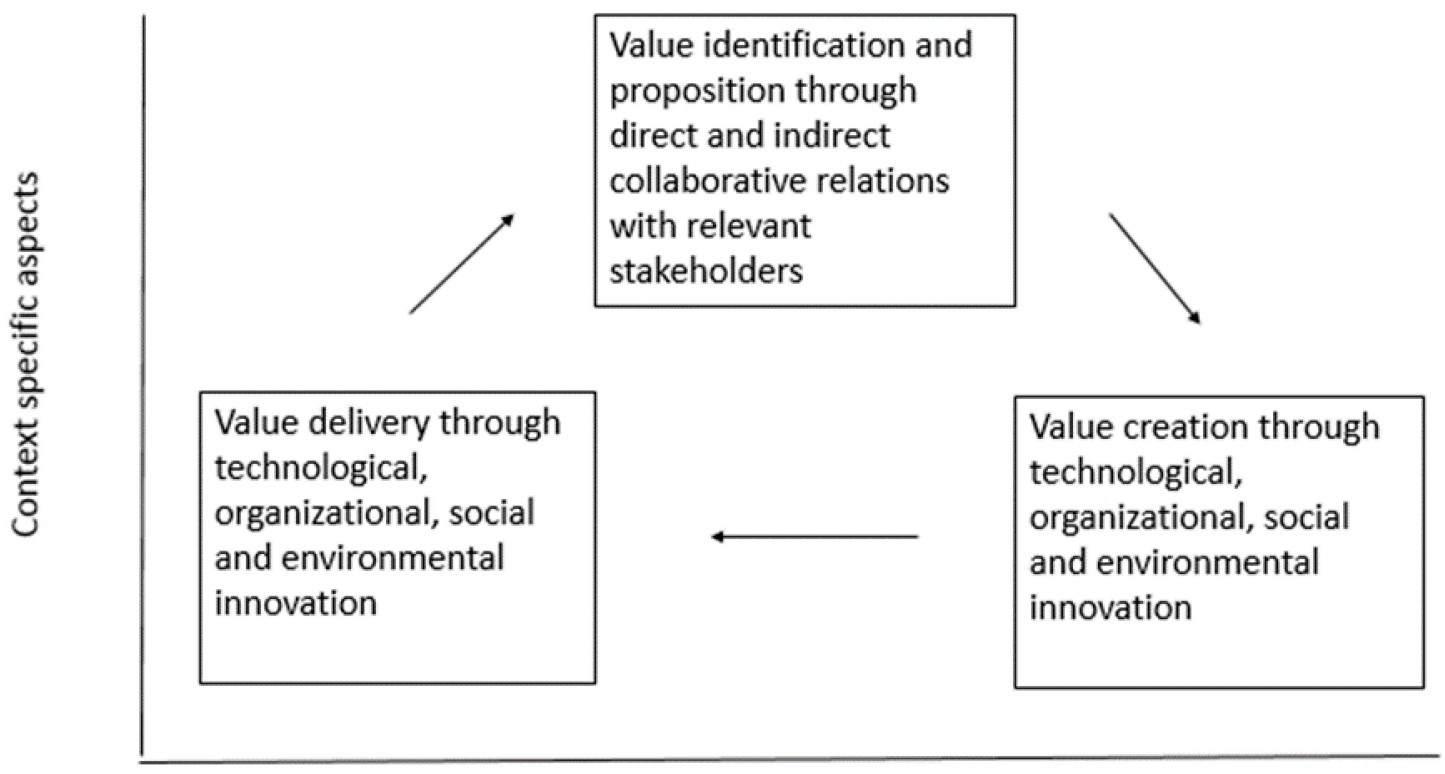

Plurality and interconnectedness

Figure 1. The main structure of the proposed SBM.

The first step in developing this model is the recognition of the specificity of each situation and of the plurality of interests, perspectives and actors that are influenced by and can influence any business. In other words, businesses are regarded as embedded in complex geographical, political, economic and socio-cultural environments. This contextual and interconnected understanding of business, inspired by both ecofeminism and Buddhism, is the main dimension of the new model and is introduced in response to the limitations of sustainability noted by some scholars [16,20]. This is illustrated in Figure 1 by the horizontal and vertical lines that frame the value-related processes. The ethical and spiritual values of care and responsibility acquire meaning in relation to such dimensions, and this influences all the model's components.

In line with other SBMs from the literature [4,23,26], the core of the proposed model is then constituted by the processes of (1) value 
identification and proposition, (2) value creation and (3) value delivery. These processes form a loop to show that the actions of each actor involved in the process of value identification and proposition development will affect all the latter processes and the future developments of new value identification and proposition development. The cycle is intended to indicate the long-term thinking that is central to sustainability and, at the same time, to evoke the Buddhist concept of karma.

As suggested in the recent literature about value co-creation [38-41], the process of value identification and proposition is a collective process wherein all relevant stakeholders engage in negotiations to establish what value the focal business can create and who its beneficiaries will be. During this process, the role of primary and marginal stakeholders will become evident and will constitute the premises for the engagement of each actor to varying degrees. The critical importance of this process concerns the possible scenario wherein some stakeholders may find themselves at a disadvantage due to the power mechanisms of the specific context (for example, minorities) or challenges in terms of participation and communication (for example, wildlife). This aspect concerning the participation of all the relevant stakeholders is broadly discussed by ecofeminists [54,58]. In the proposed model, it is the business's responsibility to include stakeholders who might find themselves in weaker positions: this could be done, directly when possible, or indirectly, through associations and expertise that can fairly and competently represent such stakeholders (for example, NGOs). The latter may also be involved in the communication of the value proposition (for example, through the establishment of certification systems).

The second and third processes are also collective, as the focal business may require various collaborative relations to create and to deliver the identified values. Such collaborations may include suppliers, research and development institutions, intermediaries and customers. For both processes of value creation and delivery, the identified archetypes' groups are related to technological, organisation, social and environmental innovations. The innovation of this part of the new model, in comparison with the framework developed by Bocken et al. [4], resides in the latter two groups of archetypes. The social archetypes are inspired by the Buddhist "Right Livelihood", and include functionality and sufficiency. In particular, sufficiency can be viewed as a choice of moderation and a form of practical commitment to contribute to a more just society. The new archetype labelled "well-being” is understood in eudaimonic terms and can be related to the search for a meaningful life that maintains a distance from materialistic desires, "tanha", and aspires to genuine self-development in harmony with others.

A fourth group of archetypes concerning the natural environment includes sentient beings other than humans, and nonsentient beings. The 
addition of this group of archetypes to the classification of archetypes by Bocken et al. [4] is intended to highlight the view of nature not only as a possible resource for human activities-businesses included-but also as an entity itself, as advocated by ecofeminists. This implies a broadening of the concept of sustainability as suggested by Shearman [22]. Relevant archetypes within this environmental category include businesses' stewardship role and entangled empathy. The stewardship role, included also in the framework by Bocken et al. [4], is based on the consideration of the natural environment at the level of ecosystems and can be understood in terms of biodiversity protection. The concept of entangled empathy derives from ecofeminism and implies the consideration of each being as having an inherent value, and the possibility for humans to establish meaningful and caring relations with nonhuman beings [57]. Entangled empathy in business contexts can be exemplified by referring to the production of goods that do not derive from the cruel treatment or exploitation of animals.

Table 2 provides a complete representation of the archetypes related to the value creation and delivery processes, for the purpose of better illustrating the contributions of this model in comparison with the framework proposed by Bocken et al. [4]. As in Table 1, some examples are provided in the third row.

Table 2. The ten archetypes of the proposed SBM, grouped in categories related to the technological, organisational, social and environmental aspects of business.

\begin{tabular}{|c|c|c|c|c|c|c|c|c|c|}
\hline \multicolumn{3}{|c|}{ Technological } & \multicolumn{2}{|c|}{ Organisational } & \multicolumn{3}{|c|}{ Social } & \multicolumn{2}{|c|}{ Environmental } \\
\hline $\begin{array}{c}\text { Max. } \\
\text { material } \\
\text { and energy } \\
\text { efficiency }\end{array}$ & $\begin{array}{c}\text { Create } \\
\text { value from } \\
\text { waste }\end{array}$ & $\begin{array}{l}\text { Substitute } \\
\text { with } \\
\text { renewables } \\
\text { and natural } \\
\text { processes }\end{array}$ & $\begin{array}{l}\text { Repurpose } \\
\text { for society }\end{array}$ & $\begin{array}{l}\text { Develop } \\
\text { scale-up } \\
\text { solutions }\end{array}$ & Well-being & $\begin{array}{c}\text { Deliver } \\
\text { functionality } \\
\text { rather than } \\
\text { ownership }\end{array}$ & $\begin{array}{l}\text { Encourage } \\
\text { sufficiency }\end{array}$ & $\begin{array}{c}\text { Adopt a } \\
\text { stewardship } \\
\text { role }\end{array}$ & $\begin{array}{l}\text { Entangled } \\
\text { empathy }\end{array}$ \\
\hline $\begin{array}{c}\text { Increased } \\
\text { functionality }\end{array}$ & $\begin{array}{l}\text { Circular } \\
\text { economy } \\
\text { principles }\end{array}$ & $\begin{array}{c}\text { Renewable } \\
\text { energy souces }\end{array}$ & $\begin{array}{c}\text { Hybrid } \\
\text { business, } \\
\text { social } \\
\text { enterprise, } \\
\text { cooperatives }\end{array}$ & $\begin{array}{c}\text { Collaboration, } \\
\text { incubators }\end{array}$ & $\begin{array}{l}\text { Eudaimonic } \\
\qquad \text { job } \\
\text { satisfaction, } \\
\text { fair trade }\end{array}$ & $\begin{array}{l}\text { Leasing, } \\
\text { sharing } \\
\text { solutions }\end{array}$ & $\begin{array}{c}\text { Consumer } \\
\text { education, } \\
\text { frugal } \\
\text { business }\end{array}$ & $\begin{array}{c}\text { Biodiversity } \\
\text { protection }\end{array}$ & $\begin{array}{l}\text { Cruelty-free } \\
\text { production } \\
\text { processes, } \\
\text { no animal } \\
\text { exploitation }\end{array}$ \\
\hline
\end{tabular}

\section{CONCLUSIONS}

The underlying position of this study is that business activity should not be isolated from our moral and spiritual lives. This study has focused on the concept of SBM. Relying on the framework developed by Bocken $e t$ al. [4], this study has developed a new conceptual model based on the inclusion of some of the main tenets of ecofeminism and Buddhism. This model proposes a contextual and relational perspective on businesses and a cyclical development of the processes of value identification and 
proposition, value creation and capture, and value delivery. The elements that are particularly highlighted in the new model are: (1) the multifaceted meaning of value for the stakeholders of the specific contexts in which the businesses operate, (2) care and responsibility toward the various stakeholders (including the natural environment), and (3) production and consumption mechanisms that aim to satisfy basic needs and eudaimonic well-being for both consumers and employees.

The proposed model can be used as a guide to the study of the underlying logic of businesses in relation to their contribution to sustainability. For example, the cyclical path of value can indicate the opportunity to conduct longitudinal studies that might highlight the possible changes in how the various stakeholders understand sustainable value. The proposed model can also be adopted to investigate to what extent barriers to change towards sustainability are influenced by contextual (geographical, socio-cultural, sectorial) characteristics in relation to the four categories of archetypes, and how businesses that act in more sustainable ways overcome such barriers. For practitioners, the proposed model may be considered a blueprint for reflection on possible directions for their businesses. Responsible managers and partners might find it useful to refer to the various archetypes to identify pathways to implement their vision of sustainability. As mentioned in the Introduction, this is meant to contribute to the avoidance of unintentional amoral management of businesses.

Some challenges can be identified in the proposed model. One is the engagement of all relevant stakeholders and the relative collective processes for identifying, communicating, creating and delivering the various types of value that can emerge from the activities of the focal business. This issue has been widely discussed in scholarship. Although very challenging, stakeholders' participation in co-creative practices is feasible when the actors are human. The task is considerably more challenging in relation to the inclusion of the natural environment as a stakeholder: the critical question here is who can legitimately represent the interests of nature. Related to this is an ulterior challenge: this concerns the SBM archetype relative to the practice of entangled empathy. The recognition of the businesses' stewardship role and the importance of the protection of biodiversity, including animals at species level, is relatively diffused in today's society, at least in theoretical terms. However, animals at the individual level are often considered to be exploitable resources and, consequently, businesses that aim to act responsibly, in relation to animals viewed as sentient beings with an inherent value, face not only possible practical challenges but also mental barriers in eventual partners and consumers. Even more challenging is the moral consideration of plants as living entities having an intrinsic value, and nonsentient entities such as rocks. 


\section{CONFLICTS OF INTEREST}

The author declares that there is no conflict of interest.

\section{ACKNOWLEDGEMENTS}

I thank the mountains and the forests surrounding the village of Ferrara di Braies for being the source of inspiration for this paper.

\section{REFERENCES}

1. Jaeger C, Tabara JD, Jaeger J, editors. European Research on Sustainable Development: Volume 1: Transformative Science Approaches for Sustainability. Cham (Switzerland): Springer Science \& Business Media; 2011.

2. Popa F, Guillermin M, Dedeurwaredere T. A pragmatist approach to transdisciplinarity in sustainability research: From complex systems theory to reflexive science. Futures. 2015;65:45-56.

3. Jahn T, Bergmann M, Keil F. Transdisciplinarity: Between mainstreaming and marginalization. Ecol Econ. 2012;79:1-10.

4. Bocken NM, Short SW, Rana P, Evans S. A literature and practice review to develop sustainable business model archetypes. J Clean Prod. 2014;65,42-56.

5. Painter M, Hibbert S, Cooper T. The development of responsible and sustainable business practice: Value, mind-sets, business-models. J Bus Ethics. 2018;157(4):885-91.

6. World Commission on Environmental Development (WCED). Our common future. Oxford (UK): Oxford University Press; 1987.

7. Elkington J. Cannibals with forks: Triple bottom line of 21st century business. Stoney Creek (Canada): New Society Publishers; 1997.

8. Becker C. Sustainability ethics and sustainability research. Cham (Switzerland): Springer Science \& Business Media; 2011.

9. Sheldrake P. A brief history of Spirituality. Oxford (UK): Blackwell; 2017.

10. Zsolnai L. The spiritual dimension of business ethics and sustainability management. Cham (Switzerland): Springer; 2015.

11. Shevchenko A, Lévesque $M$, Pagell $M$. Why firms delay reaching true sustainability. J Manag Stud. 2016;53(5):911-35.

12. Isenhour C. On conflicted Swedish consumers, the effort to stop shopping and neoliberal environmental governance. J Consum Behav. 2010;9(6):454-69.

13. Kallis G. In defence of degrowth. Ecol Econ. 2011;70(5):873-80.

14. Carroll J. Sustainability and spirituality. New York (US): SUNY Press; 2012.

15. McDaniel J. Spirituality and sustainability. Conserv Biol. 2002;16(6):1461-4.

16. Ulluwishewa R. Spirituality and sustainable development. Cham (Switzerland): Springer; 2014.

17. Banerhi S, Prasad R. Sustainable Development 2050: Spirituality-The Missing Link. Purushartha. 2019;11(2). doi: 10.21844/pajmes.v11i2.14631 
18. Carroll AB. Ethical challenges for business in the new millennium: Corporate social responsibility and models of management morality. Bus Ethics Q. 2000;10(1):33-42.

19. Lele SM. Sustainable development: a critical review. World Dev. 1991;19(6):607-21.

20. Brown BJ, Hanson ME, Liverman DM, Merideth RW. Global sustainability: toward definition. Env Manag. 1987;11(6):713-9.

21. Nandram SS, Borden ME. Spirituality and Business. Berlin (Germany): Springer; 2010.

22. Shearman R. The meaning and ethics of sustainability. Env Manag. 1990;14(1):1-8.

23. Zott C, Amit R, Massa L. The business model: recent developments and future research. J Manag. 2011;37(4):1019-42.

24. Rauter R, Jonker J, Baumgartner R. Going one's own way: drivers in developing business models for sustainability. J Clean Prod. 2017; 140(Part 1):144-54.

25. Teece D. Business models, business strategy and innovation. Long Range Plann. 2010;43(2-3):172-94.

26. Richardson J. The business model: an integrative framework for strategy execution. Strat Change. 2008; 17(5e6): 133-44.

27. Ravald A, Grönroos C. The value concept and relationship marketing. Eur J Mark. 1996;30(2):19-30.

28. Grönroos C. Service Logic Revisited: Who Creates Value? And Who Co-Creates? Eur Bus Rev. 2008;20(4):298-314.

29. Grönroos C. Value co-creation in service logic: A critical analysis. Market Theory. 2011;11(3):279-301.

30. Zollo M, Cennamo C, Neumann K. Beyond what and why: understanding organisational evolution towards sustainable enterprise models. Organ Environ. 2013;26(3):241-59.

31. Schaltegger S, Lüdeke-Freund F, Hansen E. Business cases for sustainability: The role of business model innovation for corporate sustainability. Int J Innov Sustain Dev. 2012;6:95-119.

32. Boons F, Montalvo C, Quist J, Wagner M. Sustainable innovation, business models and economic performance: an overview. J Clean Prod. 2013;45(Supplement C):1-8.

33. Boons F, Lüdeke-Freund F. Business models for sustainable innovation: state-of-the-art and steps towards a research agenda. J Clean Prod. 2013;45:9-19.

34. Roome N, Louche C. Journeying toward business models for sustainability: a conceptual model found inside the black box of organisational transformation. Org Environ. 2015;29(1):11-35.

35. Geissdoerfer M, Bocken N, Hultink E. Design thinking to enhance the sustainable business modelling process: A workshop based on a value mapping process. J Clean Prod. 2016;135:1218-32. 
36. Schaltegger S, Hansen EG, Lüdeke-Freund F. Business Models for Sustainability: Origins, Present Research, and Future Avenues. Organ Environ. 2016;29(1):3-10.

37. Abdelkafi N, Täuscher K. Business models for sustainability from a system dynamics perspective. Organ Environ. 2016;29(1):74-96.

38. Vargo SL, Maglio PP, Akaka MA. On value and value co-creation: A service systems and service logic perspective. Eur Manag J. 2008;26(3):145-52.

39. Nenonen S, Storbacka K. Business model design: conceptualizing networked value co-creation. Int J Qual Serv Sci. 2010;2(1):43-59.

40. Frow P, Payne A. A stakeholder perspective of the value proposition concept. Eur J Mark. 2011;45(1/2):223-40.

41. Frow P, McColl-Kennedy JR, Hilton T, Davidson A, Payne A, Brozovic D. Value propositions: A service ecosystems perspective. Market Theory. 2014;14(3):327-51.

42. Stubbs W, Cocklin C. Conceptualizing a "sustainability business model". Organ Environ. 2008;21(2):103-27.

43. Thaker KB. Approaches to implement spirituality in business. J Hum Values. 2009;15(2):185-98.

44. Banyhamdan KM, Harrim H, Al-Qutop MAY. Transforming an organization into a spiritual one: a five-pathway integrated framework. Int J Bus Manag. 2012;7(11):74.

45. Balog AM, Baker LT, Walker AG. Religiosity and spirituality in entrepreneurship: a review and research agenda. J Manage Spiritual Religion. 2014;11(2):159-86.

46. Giacalone RA, Jurkiewicz CL. Handbook of Workplace Spirituality and Organizational Performance. London (UK): Routledge; 2010.

47. Cavanagh GF, Bandsuch MR. Virtue as a benchmark for spirituality in business. J Bus Ethics. 2002;38(1-2):109-17.

48. Karakas F. Spirituality and performance in organizations: A literature review. J Bus Ethics. 2010;94(1):89-106.

49. Bouckaert L, Zsolnai L. Handbook of Spirituality and Business. London (UK): Palgrave Macmillan; 2011.

50. Corner PD. Workplace spirituality and business ethics: Insights from an eastern spiritual tradition. J Bus Ethics. 2009;85(3):377-89.

51. Pavlovich K, Krahnke K. Empathy, connectedness and organisation. J Bus Ethics. 2012;105(1):131-7.

52. Adams C, Gruen L. Ecofeminism: Feminist intersections with other animals and the earth. New York (US): Bloomsbury Publishing; 2014.

53. Gaard G. Ecofeminism. Women, animals, nature. Philadelphia (US): Temple University Press; 1993.

54. Shiva V, Mies M. Ecofeminism. New York (US): Zed Books; 2014.

55. Warren K. The Power and the Promise of Ecological Feminism. In: Warren K, editor. Ecological Feminist Studies. Bloomington (US): Indiana University Press; 1996. p. 19-41.

56. Donovan J, Adams CJ. The feminist care tradition in animal ethics. New York (US): Columbia University Press; 2007. 
57. Gruen L. Entangled Empathy. An Alternative Ethic for Our Relationships with Animals. Brooklyn (US): Lantern Books; 2015.

58. Warren K. The promise and power of ecofeminism. Env Ethics. 1990;12(2):125-46.

59. Curtin D. Toward an ecological ethic of care. Hypatia. 1991;6(1):60-74.

60. Casey C. Contested rationalities, contested organizations: Feminist and postmodernist visions. J Org Change Manage. 2004;17(3):302-14.

61. Bullis C, Glaser H. Bureaucratic discourse and the goddess: Towards an ecofeminist critique and rearticulation. J Org Change Manage. 1992;5(2):50-60.

62. Crittenden C. Ecofeminism meets business: a comparison of ecofeminist, corporate, and free market ideologies. J Bus Ethics. 2000;24(1):51-63.

63. Phillips M. Re-Writing Corporate Environmentalism: Ecofeminism, Corporeality and the Language of Feeling. Gen Work Organ. 2014;21(5):443-58.

64. Whitehill J. Buddhist ethics in western context: the "virtues” approach. J Buddh Ethics. 1994;1:1-24.

65. Schumacher EF. Small is Beautiful: Economics as if People Mattered. New York (US): Harper \& Row; 1973.

66. Gould S. The Buddhist Perspective on Business Ethics: Experiential Exercises for Exploration and Practice. J Bus Ethics. 1995;14:63-70.

67. Pace S. Does religion affect the materialism of consumers? An empirical investigation of Buddhist ethics and the resistance of the self. J Bus Ethics. 2013;112(1):25-46.

68. Inoue S. Putting Buddhism to work: A new approach to management and business. New York (US): Kodansha International; 1997.

69. Zsolnai L. Buddhist Economics. In: Bouckaert L, Zsolnai L, editors. Handbook of Spirituality and Business. London (UK): Palgrave Macmillan; 2011. p. 88-94.

70. Kovacs G. Buddhist Spiritual Orientation to Nature and Sustainability. In: Zsolnai L, editor. The spiritual dimension of business ethics and sustainability management. Cham (Switzerland): Springer; 2015. p. 57-68.

71. Payutto P. Buddhist economics - a middle way for the market place. Bangkok (Thailand): Buddhadhamma Foundation; 1994.

72. Harvey P. Buddhist reflections on "consumer" and "consumerism”. J Buddh Ethics. 2013;20:334-57.

73. Barnhill DL. Good work: An engaged Buddhist response to the dilemmas of consumerism. Buddh-Christ Stud. 2004;24:55-63.

74. Suh JA. Comparative Analysis of Sustainability Views across the Saemaul Movement in South Korea and the Sarvodaya Shramadana Movement in Sri Lanka. J Buddh Ethics. 2019;26:1-34.

75. Puntasen A. Buddhist economics as a new paradigm toward happiness. Soc Econ. 2007;29(2):181-200.

76. Harvey BP. An Introduction to Buddhist ethics: Foundations, Values, and Issues. London (UK): Routledge; 2000. 
77. Schmithausen L. The early Buddhist tradition and ecological ethics. J Buddh Ethics. 1997;4:1-74.

78. Gross RM. Toward a Buddhist environmental ethic. J Am Acad Relig. 1997;65(2):333-53.

79. James SP. Against holism: rethinking Buddhist environmental ethics. Environ Values. 2007;16(4):447-61.

80. Keown D. Buddhism and ecology: A virtue ethics approach. Contemp Buddh. 2007;8(2):97-112.

How to cite this article:

Bertella G. Adding an Ethical and Spiritual Dimension to Sustainable Business Models. J Sustain Res. 2019;1:e190011. https://doi.org/10.20900/jsr20190011 